\title{
Environmental Governance and Regularization of Land Ownership: development and multiple territorial dynamics in the Amazon'
}

\author{
Thereza Cristina Cardoso Menezes ${ }^{1}$
}

- Universidade Federal Rural do Rio de Janeiro, Programa de Pós-Graduação de Ciências Sociais em Desenvolvimento, Agricultura e Sociedade (CPDA-UFRRJ), Seropédica/RJ, Brasil

\begin{abstract}
This article examines how in the past two decades development standards have been established for the Amazon based on both strengthening environmental governance and expanding agriculture. It describes how the process of construction in time of an ambiguous development policy model for the Amazon, which has oscillated between territorial management based on a "green agenda" perspective and investment in policies that favored territorial security of land occupancy implemented through changes in laws and regulations concerning the environment and land ownership. Finally, I emphasize the recent convergence of interests of international cooperation, the state and agribusiness around public policies for environmental regulation based on a perspective of harmonious conviviality and positive and systemic alignment between the economy and the environment.
\end{abstract}

Key words: Amazon, deforestation, environmental regularization and of land ownership, agribusiness, sustainable development.

1 The data presented in this article are based on documental and field studies conducted in Amazonas between 2008 and 2018 in the realm of projects that I coordinated, which were financed by CNPQ (Edital Universal 2010, Edital Casadinho-PROCAD 2012 and Edital de Ciências Humanas CNPq 2015); Fapeam ( PRONEM-Fapeam 2012) and CLUA (2017). 


\section{Governança ambiental e regularização fundiária: o desenvolvimento e as múltiplas dinâmicas territoriais na Amazônia}

\section{Resumo}

O artigo examina como nas duas últimas décadas constituíram-se padrões de desenvolvimento para a Amazônia baseados tanto no fortalecimento da governança ambiental e quanto na expansão agropecuária. Descreve-se o como o processo de construção no tempo de um modelo de política ambíguo de desenvolvimento para a para a Amazônia que oscilou entre a gestão territorial fundado na perspectiva de uma "agenda verde" e o investimento em políticas que favoreceram a segurança territorial da posse da terra implementadas através de mudanças nos marcos jurídicos fundiário e ambiental. Finalmente procuro destacar a recente convergência de interesses da Cooperação Internacional, Estado e agronegócio em torno das políticas públicas de regularização ambiental ancorada na perspectiva da convivência harmoniosa e alinhamento positivo e sistêmico entre a economia e meio ambiente.

Palavras-chave: Amazônia, desmatamento, regularização fundiária e ambiental, agronegócio, desenvolvimento sustentável. 


\section{Environmental Governance and Regularization of Land Ownership: development and multiple territorial dynamics in the Amazon}

\section{Thereza Cristina Cardoso Menezes}

In early August 2019, the large surge of forest fires led the government of Amazonas state to declare a state of emergency and request federal government assistance. Data from the Instituto de Pesquisas Espaciais (INPE) [the Institute of Space Studies] demonstrated that by August 2019, the number of fires in the state increased $99 \%$ over 2018. Approximately $70 \%$ of the fires were in southern Amazonas state, where the number of fires increased 400\% over 2018. The municipalities with the most fires were: Apuí, Novo Aripuanã and Lábrea.

This article will review changes in territorial policies over the past three decades in the Amazon, highlighting the tensions, accords and ambiguities between environmental organizations, the agribusiness sector and the state in the promotion of sustainable development and agriculture in the Amazon. To do so, we sought to review the process of affirmation of a standard of environmental governance for the Amazon and the concomitant investment in agricultural development in the region. I consider data gathered in research conducted in Lábrea, a municipality in southern Amazonas state, with high levels of accumulated deforestation and where tensions between the two development models are evident over time.

I would like to emphasize that the impetus to agricultural development focused on the expansion and consolidation of the region as an epicenter of agribusiness in Amazonas has guided public policies in the region since the first government of President Luis Inácio Lula da Silva, an effort that gained strength with changes in the legal framework concerning the environment and land ownership in the government of President Michel Temer, (2016-2018), helping to understand the conditions that made it possible for southern Amazonas to become one of the regions with the highest concentrations of criminal fires in the entire Amazon.

\section{Environmentalism and developmentalism}

Since the 199os the Amazon has been a target of important investments that sought to promote sustainable development by providing financial support to the promotion of territorial policies aimed at protection of forests and traditional communities and to increase regularization of land ownership. For nearly three decades important actions were promoted in the region under the Pilot Program for Protection of Tropical Forests of Brazil (PPG7), a program that was launched in 1992 during the United Nations Environment and Development Conference, the event known as Eco-92. The legacy of the program was the demarcation of 43 million hectares of indigenous lands, an area equivalent to half of the indigenous areas in the Amazon.

The PPG7 combined proposals and resources from the world's seven wealthiest countries with counterparts from the Brazilian government, the World Bank and various international NGOs. The German government was the largest donor and responsible for $40 \%$ of the multilateral resources in the program, which sought to become "the largest program for protection of tropical forests and natural resources management in a single country, that is, the program was innovative in terms of global public policies for protection of the Brazilian Amazon Forest and Atlantic Forest" (Valente 2010: 26). 
According to information provided on the World Bank's website, with an allocation of US\$428 million, twenty-eight projects were supported and organized based on four components: 1) the creation of a national policy for natural resources management; 2) the establishment of areas of conservation and natural resources management through the demarcation of 2.1 million hectares of forest, monitored to identify deforestation and degradation in the nine states of the Brazilian Amazon; 3) financing of research centers and 110 studies about Brazilian forest systems and 4) promotion of innovative sustainable development projects in Amazon communities.

In a seminar held in Brasilia to conclude and evaluate PPG7 in September 2009, the representatives of the Ministry of the Environment highlighted among the positive results of the program the creation of more than 100 million hectares of protected areas in the Amazon and Atlantic Forest, of which 2.1 million hectares are extractive reserves, 44 million hectares of demarcated indigenous lands and 72 million hectares of ecological corridors; support for sustainable forest management initiatives, particularly sustainable lumbering; support to the organization of producer associations and the use of new production models adapted to Amazon conditions, with special attention to the use of fire in agricultural management and sustainable use of fishery resources, through agreements between communities of fisherman and companies.

The program supported the strengthening of environmental management through perfection of tools for land monitoring, inspection and regulation such as Ecological-Economic Zoning (ZEE) and the Environmental Licensing System for Rural Properties, and collaborated to the institutional strengthening of various nongovernmental organizations such as the Grupo de Trabalho Amazônico (GTA) [Amazon Working Group network $]^{2}$ and the Coordenação das Organizações Indígenas da Amazônia Brasileira (COIAB) [Coordination of Indigenous Organizations of the Brazilian Amazon], created by indigenous leaders in 1989.

In the realm of environmental policies, the PPG7 encouraged experiences for shared management between state entities such as the Public Ministries [the state prosecutors] and state environmental agencies, allowing the creation of the Forum of the Public Ministry, which joined the nine states of the Amazon region to strengthen legal defense of the environment. The PPG7 also steered the preparation of the Sustainable Amazon Plan (PAS), which sought to adapt planning for Amazon development proposed by the federal government to the standard of environmentally oriented development underway in the Amazon through a planning policy expressed in the Action Plan for the Prevention and Control of Deforestation in the Amazon (PPCDAm), and a Sustainable Regional Development Plan for the Area of Influence of Federal Highway BR-163 (BR 163 Sustentável program).

In 2008, another important program to protect forests and combat climate changes was the Amazon Fund, the main financial support for which came from the Norwegian and German governments, which was implemented by the Ministry of the Environment and administered by Brazil's National Development Bank (BNDES). The Amazon Fund became the most important tool for promoting conservation actions in the Amazon and for preventing, monitoring and combatting deforestation.

Approximately R $\$ 1,8$ billion was issued to projects. Nearly $60 \%$ of the fund's resources were aimed at the federal government, states in the Legal Amazon ${ }^{3}$ and agencies that work with the environment and inspection such as the Brazilian Institute for the Environment and Renewable Natural Resources (Ibama) and the National Institute for Space Research (Inpe). Nearly $40 \%$ was invested in non-governmental organizations and universities. In 2018, Norway and Germany threatened the Brazilian government that they would withhold funds due to

\footnotetext{
2 The GTA network is formed by 20 organizations from nine Brazilian states, combining some six hundred entities that represent farmers, rubber tappers, indigenous peoples, quilombola residents, fishermen, ribeirinhos and representatives of various traditional communities, as well as environmental and human rights entities.

3 The Brazilian Legal Amazon corresponds to a region legally defined for purposes of regional planning and public policy with a total area of 510 million ha, encompassing all of the northern region and parts of the centre-west and northeastern regions. Legal Amazonia includes seven states of the North Region (Acre, Amapá, Amazonas, Pará, Rondônia, Roraima and Tocantins), as well as part of Mato Grosso in the Center-West Region and most of Maranhão in the Northeast Region.
} 
the growing rates of deforestation from 2015 to 2016. According to data from INPE, in mid 2019, deforestation was $88 \%$ more than in the same period in 2018. Also in mid 2019, the minister of the environment proposed that resources from the Amazon Fund be used for the regularization of land ownership, that is, employed to indemnify rural land owners who had their lands appropriated because they were within environmentally protected lands.

Among the interpretations for the large amount of investment in sustainable development in the Amazon, Paula (2013: 24) proposes that this set of actions is based on the concept of "green capitalism". This is an expression of real transformations operated in capitalism to promote a simultaneous movement of adaptation to a new international division of labor, to reordering of a geopolitical nature, reconfigurations in statemarket relations and the assimilation of environmentalism in the process of globccal accumulation". The green economy would constitute a new cycle of capitalist growth, based on greening of the entire economy, a concept based on the presumption of "ecoefficiency" as a new support for capitalism. Based on this interpretive scheme, Harvey (2016: 231) affirmed that "environmental protection" functioned as greenwashing, a mask to disguise actions with profitable purposes with practices for collective well-being.

According to Rist (2007), since 1949, when the term "development" was mentioned in a speech by US President Harry Truman, it has been used as "an evasive buzzword for beliefs and suppositions about social progress that vary as a function of where and by whom it is used, an undebatable truth that permeates the modern world". Since then, in the circle of international relations, colonizers and colonized, became converted into more or less developed countries, "apparently equal members of a single family", in which time, money and policies would resolve the differences between the two sides.

For Rist, the word development began to acquire a performatic character, related to the implementation of that understood development to be a more homogenous process, which promoted a wide and contradictory variety of measures justified in the name of "improvement of life of poor people or in defense of a fair and desirable world order".

In 1987, the promotion of the Brundtland Report by the United Nations World Commission on Environment and Development of the United Nations (CMMAD 1988) coined the term "sustainable development", proposing the conciliation of objectives for environmental protection with guarantees of economic growth. According to Rist (2007), "sustainable development is nothing more than a paradox, a figure of rhetoric that unites two opposites, such as capitalism with a human face and "humanitarian intervention". To neutralize and overcome the beliefs of the jargon of "development" and its association to adjectives that seek to dignify it Rist (2007, 2008) proposes a sociological and non-normative definition of the term, by considering the historic process that consolidated it, that is "it should not be based on what it thinks that development is or what it wants it to be, but on its real social practices and their consequences".

In the case of anthropology, various readings about the theme of development arise at the heart of the criticism of the discipline as being a form of "colonial knowledge" (Asad, 1973; Said, 1990). Inspired by the work of Michel Foucault and supported on the concept of governability, Ferguson (1990) and Escobar (1995) sought to address the functioning of the mechanism of development. Ferguson (1994), based on a study conducted in Southern Africa, analyzed how transnational discourses are incorporated to the construction of states, conferring special attention to the production of an apparatus of international agencies, aimed at classifying and characterizing less developed countries, and in this way, imposing on them state interventions that they supervise. The development agencies create what Ferguson calls an "anti-politics machine", that is, a process that naturalizes neoliberal paradigms of development and self-determination associated to a certain concept of progress defined from the outside, producing internal resistance that culminates in the failure of external intervention. 
Escobar (1995), based on an examination of development initiatives implemented in Colombia, highlights that the process produced disciplines (as an effect of the instrument) based on a rational mode of government founded on economic growth programs for the production of well-being in populations characterized as "poor". From this perspective, development would constitute a mode of understanding the real. In more recent studies about indigenous and Afro-descendent populations of the Colombian Pacific, Escobar (2008) complexifies this approach and calls attention to the possibility for reconfiguration and the transformative potential of certain alternative development practices.

\section{The Case of Southern Amazonas}

In early 2011, representatives of government agencies and civil society from Amazonas, Mato Grosso and Rondônia, presented the Ministry of the Environment a letter calling for the creation of the so-called Mosaic of the Southern Amazon. The document made official the request that the federal government create a "mosaic", which is an instrument determined by article 26 of federal law 9.985 - the National System of Conservation Units (SNUC). A mosaic is a combination of various conservation units into a single legal entity, which encompasses the territories of various protected areas and has the objective of strengthening the integrated management of the units, to promote institutional articulation in a broad territorial base and reinforce the identity and territorial order of a single region.

In August 2011, the Mosaic of the Southern Amazon was recognized by the Ministry of the Environment, combining 40 state and federal conservation units, totaling some seven million hectares in southern Amazonas, north and northwestern Mato Grosso and western Rondonia - an environmentally vulnerable region, because it is part of the "Arc of Deforestation", a region recognized because of a large number of burnings and the advance of deforestation.

The guidelines for the creation of the Mosaic were discussed at length in five workshops held over four years with participation of the State Center of Conservation Units of the Secretariat of Sustainable Development of Amazonas (Ceuc/SDS); the secretariats of the environment of the states of Rondonia and Mato Grosso; ICMBio; the German Technical Cooperation Agency (GTZ) and the World Wildlife Foundation Brazil (WWF-Brasil). The measure was expected to encourage a conjugation of efforts at state and federal levels to execute activities for protection of the region, which would serve as a barrier to the strong surge of deforestation coming from Mato Grosso, and Rondonia towards Amazonas.

As efforts were concentrated for the creation of the Mosaic of the Southern Amazon, in August 2011 state law no 3.645 was implemented, the Economic-Ecological Zoning (ZEE) for the sub-region of Purus, in southern Amazonas, including the municipalities of Lábrea, Canutama, Tapauá, Pauini and Boca do Acre. This area has $252,985 \mathrm{~km}$ and corresponds to $16.1 \%$ of the territory of Amazonas state. The ZEE of Purus allows recomposing of the Legal Reserve ${ }^{4}$ on only $50 \%$ of the deforested area.

The proposal to reduce the Legal Reserve for purposes of recomposition encompassed a total area of 4,216.84 $\mathrm{km}$, corresponding to $1.68 \%$ of the territory of the sub-region of Purus. The proposal for the area sought to benefit 582 properties in the region, of which 434 are located in the municipality of Lábrea. According to the then president of the Federation of Agriculture of Amazonas, the ZEE would be a historic mark for rural farmers in the region, who for years awaited recognition of the area of the BR 317 (the Trans-Amazon Highway) region and southern Lábrea as areas where agricultural production had been consolidated.

\footnotetext{
4 "The preserved area, known as the legal reserve (reserva legal), must be recorded in the land title and the location of the preserved área cannot be subsequently altered (...). In addition to being prohibited from removing the vegetation from areas along rivers and other water bodies as well as steep slopes and hilltops, private landowners are obligated to keep parcels of their land in native forest" (Alston; Miller 2007).
} 
Since 2007 I have conducted research in southern Amazonas, and as mentioned, the region has become a scene where a wide variety of development policies have been promoted. The region, especially the municipality of Lábrea, has stood out in the past two decades for the presence of socio-environmental organizations that have executed projects to promote sustainable development, particularly for communities on Indigenous Lands and on Conservation Units, thus constituting instruments for command and control of territorial zoning, understood as the dimension of "administrative policy" (Nitsch 1994).

The initiatives of these entities concentrated on actions for technical-pedagogical assistance to the implementation and strengthening of local instances of governance of the Policy for Territorial Management of Indigenous Lands, initiatives for training in sustainable management and integration of chains of forest products and territorial monitoring. In parallel to the impetus to socio-environmental development for the region, an increase in pasture land was observed, especially in the advance strip of the agricultural frontier, which is how the advancing area of pasture land is known, as well as growing violence against leaders and pressure to appropriate traditional territories.

The financing of socio-environmental projects in the southern Amazonas came from Brazilian and international agencies. ${ }^{5}$ The actions focused on the better preserved areas of the region with limited action or no action in the areas of greater pressure from the "agricultural frontier". In the municipality of Lábrea, which is considered the most violent and that which has the most conflicts over land ownership in the state, particularly the regions that border the states of Rondônia and Acre, interviews with technicians of the socioenvironmental project staff in the region revealed a lack of knowledge about the most combative regions. On various occasions I was asked with curiosity about "how things were there in the south of Lábrea", given that the area frequently appeared in the news about agricultural conflicts in Amazonas. The offices of the socio-environmental organizations are located in the center of the municipality, which is relatively far from the center of conflicts.

Although they do not act directly in the areas of greater tension, it should be highlighted that the administrators of the organizations were always aware of the gravity of the territorial conflicts. During the study, one of the socio-environmental organizations that works in Lábrea promoted an event at the municipal offices that brought together many of the leaders who were being threatened in the municipality, with representatives of the National Agrarian Ombudsman, and helped to place community leaders in witness protection programs and those for human rights defenders.

I accompanied the trajectory of some leaders in the municipality and found that these support actions were isolated and that the permanent accompaniment and support for threatened leaders in the southern region of the state was made mostly by members of the Pastoral Land Commission of Amazonas, based in Manaus, which for many years accompanied the daily conflicts and helped leaders in southern Amazonas.

It should be noted that in the areas that were the focus of action of the socio-environmental projects, there were also numerous conflicts. At the workshops for social mapping that I conducted in various indigenous communities with extractive activities in the municipalities of southern Amazonas, through the Projeto Nova Cartografia Social da Amazônia, [The New Social Cartography Project for the Amazon], ${ }^{6}$ I conducted various interviews in which I heard frequent reports about the advance of cattle raising, work analogous to slavery, interdiction of extractive activities by land owners, and the presence of lumberers, hunters and fishing on Indigenous Lands and in Conservation Units. A dynamic was observed in which environmentalists and landowners each executed their projects in southern Amazonas, respecting the established borders of action.

5 The financial partners include, for example: the Amazon Fund, the US Agency for International Development (USAID), Gordon and Betty Moore Foundation, German Technical Cooperation Agency (GTZ), Brazil's National Indian Foundation (FUNAI), and Petrobras.

6 I was a researcher in the Project from 2007 to 2014 and conducted various workshops for mapping leaders and residents of Indigenous Lands and Extractive Reserves in Lábrea, Canutama, Tapauá and Pauini. 
Significant ruptures in this division took place through investments by the state that obeyed the conjunctural dynamics of coalition building, which would harm or benefit the forces that operated in the Amazon.

One example of the ambiguities of government action was the creation in May 2016 of five new federal Conservation Units in the Amazon, one day before President Dilma Rousseff was deposed. The act was considered a reprisal to legislators from Amazonas who voted for impeachment. The conservation units totaled 2.7 million hectares, all located in southern Amazonas, in municipalities which concentrated large agribusiness, mining, and energy production interests and that had a steep rise in deforestation between 2014 and 2015.7 These new areas coincide with the territories of traditional communities that have long been demanding official recognition of their lands, and constitute a barrier against expansion of cattle raising, lumbering, and soybean farming in southern Amazonas and northern Mato Grosso and Pará.

The reaction was immediate and legislators, mayors and the Federation of Agriculture and Husbandry of Amazonas (FAEA) emphasized that the implantation of Conservation Units would bring great harm to the state and proposed the reduction of the reserves. According to a technical note from Instituto Socioambiental (2017), in 2017205 mining processes had been registered in the five conservation units. Most of the processes referred to authorization for research about the presence of gold. Also in 2017, there were 162 properties with an average size of 6.2 thousand hectares, that is large latifundium, registered in SICAR (Rural Environmental Cadaster System) within the areas of the five conservation units.

The analytical horizon adopted in this reflection perceives the state as a non-monolithic object, but one in a process of formation and constant revision that manifests a convergence of symbolic forms and structures of apprehension of the world, constituting itself as an instrument that not only imposes or reduces outside impositions, but gestates and administers them (Souza Lima 2002). The argumentation presented seeks to understand how the Brazilian state assumed multiple forms and prerogatives, establishing distinct coalitions due to the political support, reprisals and various interests in play, in particular configurations of the political field.

My objective is to demonstrate how the Brazilian state incorporated a standard of territorial policy for the Amazon anchored on proposals for sustainable development. It is thus clear that the process of territorial reconfiguration based on the presumptions of a "green agenda" did not expand homogeneously and consensually. An examination of regional configurations such as those found in southern Amazonas demonstrate the ambiguities of state actions that either favored or created obstacles to development processes of quite distinct natures. This process obeys conjunctural and structural logics related to the interdependence between the state and internal and external political forces.

It should be noted that this examination of local configurations is also essential to understanding the scope and field of possibilities for action. Environmentalism exercised decisive influence on recent development in the Amazon, with international support and from various excluded social segments, but was also characterized by a difficulty to construct local and regional alliances, which usually manifest a tendency to support local elites and reproduce the hegemony of the developmentalist discourse (Garnelo and Sampaio 2005).

\footnotetext{
7 The conservation units are located in the municipalities of Apuí, Novo Aripuanã and Manicoré. According to data from PRODES/INPE, between 2014 and 2015, Manicoré had a 237\% increase in deforestation, Nova Aripuanã (122\%) and Apuí (41\%) . In 2015, Apuí and Manicoré were among the municipalities of the Amazon with the most deforestation. The new conservation units created in 2016 include: three for sustainable use: the Environmental Protection Area of the Campos de Manicoré, the National Forests of Aripuanã and Urupadi; and two for integral protection: the Biological Reserve of Manicoré and the Acari National Park.
} 


\section{The dynamic of the advance of agribusiness}

An analysis of cadastral data from INCRA, Texeira (2011: 7) detected that in the first decade of 2000 land concentration in Brazil, particularly in the Amazon, become more imbalanced, indicating that despite the formation of a large socio-environmental mosaic, the frontier of expansion of agribusiness was expanding. In the period from 2003 to 2010 , according to Teixeira, the area registered within the category of large properties increased from $61 \%$ to $84 \%$ of territory in the Amazon (including all of Maranhão).

The numeric explosion in the areas registered in the Amazon would be linked to a surge in declarations generated by expectations of federal actions related to land ownership regularization in the region. Historically, one of the main difficulties in promoting regularization of land ownership in the Amazon was the so-called "unorganized process of occupation" (Idem p.2), which in large part had been stimulated by the federal government in the second half of the twentieth century. It has been common to find various lands illegally registered due to a combination of collusion between private land deed registration offices with the criminal action of land grabbers, as attested by a Parliamentary Investigative Commission Land Grabbing of Public Lands in the Amazon (2001) formed by Congress, which led to the cancelation of 50 million hectares of land registrations in Amazonas state alone.

The Lula government (2003-2010) provided strong stimulus to commercial agriculture, a fact revealed by Lula's naming of the leader of the Brazilian Association of Agribusiness, Roberto Rodrigues, to be Minister of Agriculture. The harvest in the first year of the Lula government was a record and the international agricultural trade had a strong surplus in the first years of his government. Great efforts were made to meet the financing needs of the sector and facilitate international business to reduce export barriers to the United States and the European Community.

In 2004, as a result of the advance of agriculture in the Amazon, denunciations rose in Brazil and abroad that widely reported the explosion of deforestation in the Amazon. In that year, 27 thousand $\mathrm{km} 2$ were destroyed (equal to the size of Alagoas state). The data revealed an increase of more than $100 \%$ in deforestation in relation to 1997 , and a considerable expansion in soybean farming in the northern region, which was an important cause of deforestation. In 2006, the Greenpeace environmental group published the report "Eating Up the Amazon" (Greenpeace 2006), which demonstrated how agribusiness and the international soybean market financed the opening of new crops in areas of Amazon forest, nourishing a productive chain that began with the deforestation of the Amazon and ended on European tables.

Concerned with their public image, international food sector corporations and soybean traders operating in the Amazon began a dialog that resulted in an agreement to reduce deforestation in the tropics, known as the "soybean moratorium". That is, after 2006, companies agreed to not purchase soybeans cultivated on deforested lands in the Amazon biome and or from farmers who exploited workers in conditions analogous to slavery.

The effects of the agreement and increased monitoring were felt from 2004 to 2015, a period during which a sharp drop was noted in deforestation in the Amazon, resulting from integrated actions like increased exploration of already deforested areas, rational management of cattle herds and intensification of inspection actions by environmental agencies. Environmental organizations and agribusiness sectors took credit for the decline in deforestation. In the media, Greenpeace highlighted the Soybean Moratorium as "an enormous step to stop deforestation of the Amazon" and the multinational soybean producer Cargill promoted the pact as "a resounding success" (Torres, M. and Branford, S. 2017).

Since the 199os, the federal government was pressured to halt the historic uncontrolled occupation of lands in the Amazon and seek means to execute a policy of land ownership regularization in the region through the implantation of Law no 8.666/1993, which limited to 100 hectares the maximum concession of property of public lands for those who reside or produce on them. In 2005, this law suffered important changes that expanded 
this limit to 500 hectares, ( Lei 11.196/2005) and then, through provisional measures that became law, the limit reached 15 fiscal modules, or up to 1,500 hectares, a size that can hardly be considered a small family property.

Legal insecurity was always seen as an obstacle to the advance of the agricultural frontier in the Amazon, a region that had at the end of the first decade of the twenty-first century between 58.8 million (federal lands) and 100 million hectares to be regularized, if counting the lands under the control of the states and under management of their land institutes. In 2008, the Secretariat of Strategic Affairs (SAE) of the Presidency of the Republic and the International Bank for Reconstruction and Development (BIRD) held in Brasilia the International Seminar "The Challenge of Regularizing Land Ownership in the Amazon", which supported the federal government's negotiations with the nine governors of the Legal Amazon region, concerning regularization of land ownership in the region. The conditions converged to have regularization of land ownership considered the primary problem in the Brazilian Amazon.

In keeping with the new situation of growth of production of commodities in the region and a progressive tendency to place federal public lands under the administration of state governments in the Legal Amazon, the process to accelerate regularized allocation of public lands became imperative. To combat the "chaos in land ownership" in the Amazon in 2008, the political scientist Mangabeira Unger was made responsible for the "Sustainable Amazon Program" (PAS), which was organized within the formulation of a development agenda for the Amazon region that emphasized the regularization of large areas of public lands. During his administration, Mangabeira Unger traveled to states of the Amazon region in meetings with representatives of the agricultural sector and formulated the proposal that gave origin to the law that would regulate the Programa Terra Legal [Legal Land Program]. This measure created legal mechanisms to authorize the transfer of public lands to private parties without a public bid process.

The federal government launched a proposal to conduct georeferencing of all lands in the country by 2020, to create a single data base that would be fed by Incra and state land institutes. Based on this perspective the Legal Land Program was launched in 2009 to promote the regularization of land ownership of occupations based on peaceful and uncontested possession within federal lands in the Legal Amazon. The program was based on Law 11.952, which was sanctioned by former President Lula in 2009. Federal lands in the Amazon encompassed an area equivalent to more than of the Amazon territory.

The allocation of public lands was to be justified by their use for public and collective purposes, as in the case of indigenous lands, conservation units and agrarian reform settlements, or that is, uses that take precedent over private ones. The Legal Land Program was an ambitious program, proposing to regularize $8 \%$ of the Legal Amazon with the goal of providing legal security to farmers in the Legal Amazon, associated to the reinforcement of public policies for environmental preservation.

One of the main effects the new program was to reduce the participation of INCRA in the legalization of lands, although the program used the agency's land ownership base and some of INCRA's experienced technical staff. In Amazonas, for example, the Legal Land Program even occupied INCRA facilities. The conflicts over responsibility for the program soon arose, and the National Confederation of Associations of INCRA employees accused the Legal Land Program of promoting agrarian reform as a complementary program to regularization of land ownership.

Immersed in a trajectory of institutional tensions, polemics and suspicions of irregularity since 2009, the year of its implementation, the Legal Land Program was audited by the Federal Budget Court (TCU), which examined some operations of the program from February 2009 until July 2014. The survey found low operational production and insufficient level of internal controls of the operations.

In southern Amazonas state, the collective projects for land registration under the Legal Land Program were episodes rife with irregularities. Interviews with small farmers indicate that large farmers in the region were treated with privileges by the program's land registration staff. The coordinator of the Technical Division 
of the Legal Land Program in Amazonas argued at a meeting in the south of the municipality of Lábrea "that the documentation of that area where they live for many years was already regularized and that their only remaining option was to leave immediately" (Menezes 2015: 126). The perspective of regularization intensified the processes of appropriation of lands. The conflicts intensified and the pressure from large farmers on small farmers to sell land for low prices forced many small farmers and extractivists to abandon the location. Local leaders were assassinated or received death threats and had to leave the region.

The Monitoring Report for the Legal Land Program prepared by the Federal Budget Court $(2014,14)$ concluded in mid 2014 that of the 7,951 processes for granting land deeds, 5,607 refer to areas smaller than a fiscal module (MF) [one thousand hectares] totaling 174,577 hectares; 2,056 processes were for land from 1 to 4 MFs totaling 263,429 hectares and 292 processes were for lands larger than four MFs totaling 170,947 hectares. The states with the most land deeds larger than four fiscal modules were those with greater impulse in expansion of the agricultural frontier: Pará, Mato Grosso, Tocantins and Maranhão.

The report of the budget court also highlighted that $47 \%$ of the land deeds issued were questioned for reasons such as the beneficiary held a full-time public or private job, was a partner in a non-agricultural company or was resident in another state. Although direct occupation by the property owner was one of the conditions of the program - to assure the social function of land - in 47 situations directly analyzed by the Budget court there was no direct occupation in 13 o them. The court found that there was a lack of any accompaniment or checking of the use of the properties for which title was granted under the program.

At the rhythm of issuing titles attained by the program from 2009 to 2014, four more decades would be needed to reach the proposed goals. The inefficiency and slow movement of the land ownership regularization process in the Amazon was the basis for the creation of the Intergovernmental Executive Group for the Regularization of Land Ownership in the Legal Amazon (GEI). This group was created to establish guidelines to accelerate the process of allocating public lands in the Amazon, led by the following government representatives: the Office of the Presidency of the Republic, the Secretariat for Strategic Affairs of the Presidency of the Republic, the Secretariat for Institutional Relations of the Presidency of the Republic, the Ministry of Agrarian Development, the Ministry of the Environment, the Ministry of Planning, Budget and Management, the Ministry of Cities and the National Institute for Agrarian Reform and Settlement (INCRA).

To accelerate the procedures for regularization of land ownership, the meetings of the Intergovernmental Executive Group included participation of state governors, and other government representatives such as state coordinators of the Amazon Legal Land Program. The meetings improved ties between the Legal Land Program, secretariats of land ownership programs, and land institutes and ministries, bringing together those who implemented land ownership policies to simplify the legal measures, leading to a debureaucratization of regularization. As a result, agreements were signed to make more flexible the documentation needed for regularization, assuring simplicity and agility, to increase the number of rulings favorable to the issue of definitive land titles.

Beyond the simplification of technical procedures, one of the bottlenecks to increasing the number of definitive land titles was the need to make more flexible the norms associated to Law 11.952. During a meeting of the GEI an agreement was approved that changed a normative guideline of the Legal Land Program, making it possible to regularize title by occupancy within plots of land without requiring that the perimeters be georeferenced, as long as there was no limit with the land plot itself.

Simplifying and accelerating the regularization of land ownership became a way to escape the criticisms traditionally aimed at INCRA, which accused the agency of not having the ability to implement its responsibilities in the Amazon. During the government of President Dilma Roussef, the GEI adopted measures to simplify the land ownership regularization process, through administrative measures that increased agility and the number of definitive titles under supervision of the German Technical Cooperation Agency (GTZ). With this 
orientation, the size of lots in agrarian reform programs increased from 1 fiscal module to 2, based on the experience of the Legal Land Program in the Amazon, undertaken in the area destined for the regularization of the Rio Juma/AM Settlement Project (Law no 13.001, 20 June 2014).

Beyond the requests to regularize rural properties larger than 15 fiscal modules, there were also requests to renegotiate debts of the former title holders and to legalize regularization processes that had been denied due to land grabbing, as took place in the southern portion of Lábrea, the region mentioned earlier. These procedures contributed decisively to the change in the process of land regularization, with a considerable increase in the issue of definitive land deeds.

According to an interview with the Secretary of the Special Secretariat for Family Agriculture and Agrarian Development (MDA 2017), the changes and innovations brought by Provisional Measure (MP) 759 (known as the Land Grab MP and later sanctioned by President Michel Temer as Law 13.465/2017) were essential to the continuity of the work developed by the Legal land Program, especially in terms of its debureaucratizing, pacifying, egalitarian and universal aspects. Interviews with technical staff from the Legal Land Program revealed that the Provisional Measure responded to many demands presented to the GEI, that sought to significantly increase the legalization of lands, therefore MP 759 would be an outcome of this movement, or better, a result of the articulations undertaken over time in the GEI that sought to construct a Legal Land Program without bureaucracy.

The new legislation allowed for the regularization of continuous areas up to 2.5 thousand hectares and that occupants prior to July 2008 participate in the process. Incra set values for bare land based on values applied to agrarian reform. Areas of more than 2.5 thousand hectares could be partially regularized up to this limit and payments could be spread over 20 years, with a three-year grace period, maintaining the previous rule. The new law was seen by opposition senators as a "present to large landowners" to promote the reconcentration of lands, facilitate the actions of land grabbers throughout the country and weaken small property owners.

Before the law was sanctioned it began to effects due to the expectations for regularization, influencing the price of land in the Amazon. Data collected by satellites of the National Space Research Institute (INPE) and released by the Deforestation Monitoring Project of the Legal Amazon (PRODES) revealed that some 8 thousand square kilometers of land were deforested between 2015-2016, a $30 \%$ increase in relation to levels in the previous decade. Given the alarming data, Norway, one of the most important international financers of projects for environmental protection and to prevent and monitor deforestation in the Amazon, announced a large financial aid cut.

After the president sanctioned the law, the estimate was that 27 thousand rural and urban titles would be issued in the nine states of the Legal Amazon, benefitting more than 300 thousand people. As demonstrated, the new Legal Land Program was derived from the eight previous years of attempts to make the implementation of land regularization in the Legal Amazon more agile. The new law reduced the bureaucracy involved in land regularization as it has been conducted, issuing title to millions of hectares of federal lands that attracted agribusiness investments. Below I present some of the changes brought by the new law that allowed accelerating the process of formalization and making lands available in the market:

- A change in the method of calculating the value of the titles, which came to use a table of prices more accessible to farmers, by considering the purchase price of land by the land agency and not market values;

- Uniformization of the base for calculating prices between the policies for land regularization and agrarian reform;

- Change to the clauses of the deed titles, to allow demonstration of their compliance in a more objective and quicker manner; 
- Prevision of the legal hypothesis for release from conditions after the three-year grace period;

- The possibility to adjust the values of the titles already issued to the new parameters;

- The possibility for financial compensation of beneficiaries in case of social interest for the creation of agrarian reform settlement projects;

- The concession of a time period to renegotiate delayed payments for land titles;

- Prevision for direct sale of property, to expand the reach of the Legal Land Program in the Amazon

Another important change related to the new laws and regulations governing land regularization is that since 2017 the employees of the National Institute for Agrarian Reform and Settlement (INCRA) have been encouraged to distribute individual titles of land property to the largest possible number of occupants of agrarian reform settlements. When INCRA employees turn on their computers, they find on the screen a "deed-meter", which is a ranking that establishes goals for land regularization and rewards the regional offices that issue the most titles with laptop computers. The deed-meter reveals the current priorities of land policy, that is, to abandon the policy of agrarian reform and promote family agriculture in detriment to the emphasis on individual titles.

According to INCRA data, between 2015 and 2016 the number of families settled in agrarian reform projects fell $94 \%$, while the number of title deeds for occupancy issued increased $502 \%$. Once families receive land deeds, they are no longer served by agrarian reform policies and no longer beneficiaries of low interest financing. In this adverse context, there has been a tendency for them to sell lands, leading to a reconcentration of land ownership and an intensification of the land market. It is important to highlight that the policy for emancipation of rural settlements has been accompanied by a progressive reduction in the provision of resources to support settlements and individualized regularization has become the only remaining way to access land.

In addition to the change in the legal conditions for land regularization, another important change took place in 2012 with implementation of the country's New Forest Code (Lei no 12.561/12). The approval of the law generated a strong polemic. Environmentalists and sectors of civil society perceived the new code as a norm that would drastically reduce the parameters of conservation in comparison with the previous law and would favor the intensification of deforestation in the Amazon.

One innovation brought by the code was related to the monitoring of large properties and areas for family farming, which were now subject to implementation of the Rural Environmental Cadaster (CAR), which was proposed as a mechanism to help government administer the use and occupation of land in relation to environmental issues. It was an electronic public record, created in the realm of the National Environmental Information System (SINIMA), and was mandatory for all rural properties.

The objective of the CAR was not to recognize ownership or title to occupancy and did not substitute registration with the National Rural Cadaster System of the National Institute for Agrarian Reform and Settlement (INCRA). However, its implementation has already had important influence on the dynamics of land ownership in the Amazon. Since 2012, the date of implementation of the CAR, the deadline for registration has been postponed four times and only $5 \%$ of cadasters have been validated. ${ }^{8}$

CAR is a management tool that gained legitimacy through previous experiences (nearly 21 projects, in nine states) that used remote sensors to identify, control and fight deforestation in the Amazon region (Savian et al 2014). The origin of the Cadaster is linked to the Environmental Licensing System on Rural Properties (SLAPR), which has been implemented since the year 200o, through the Mato-Grosso Program for Rural Environmental Regularization (MT LEGAL). Currently, the inscription in CAR is mandatory and self-declaratory.

8 In September 2019 an agreement between agricultural associations and environmentalists allowed the federal Chamber of Deputies to turn into law the Provisional Measure (MP) for the Rural Environmental Cadaster (CAR), MP 884. The measure allows registration and updating of information in CAR at any time. 
From the moment that an inscription is activated, it allows farmers to access benefits foreseen in the Forest Code. The responsibility for the information is up to the declarant and must be updated periodically and evaluated by the responsible environmental agency.

Once inscription in CAR is made, those responsible for properties with environmental damages, or that have Areas of Permanent Preservation (where building, land clearing, or grazing is not permitted) or considered Legal Reserve before 22/07/2008 can adhere to the Environmental Regularization Programs (PRA) of the states to regularize the property. Rural properties that have more native vegetation than required by law or of legal reserve, an environmental "right-of-way" or quotas of environmental reserve, can negotiate these surpluses with those properties pending regularization, as long as they are located in the same biome. This negotiation can take place through different modalities, including the Acquisition of the Environmental Reserve Quota (CRA).

Although the CAR cannot be used for the purpose of regularization of land ownership, but only for environmental purposes, representatives of the Federal Public Ministry of Pará have been warning about the use of CAR as a document for regularization of properties or as proof of title of occupancy and ownership, allowing access to public policies to obtain benefits from federal programs such as a Declaration of Aptitude in Pronaf (a family farm program with low interest loans), Minha Casa Minha Vida (a low cost housing program) and access to ICMS Verde (tax benefits). In various cases the CAR has been used to begin a process of land regularization on public lands, that are later sub-divided and sold (CHIAVARI et al 2016). In southern Amazonas, the 11 largest CARs registered overlap with conservation units created in the region in May 2016. The largest cadaster was made five months after the creation of the areas and has 250 thousand hectares, coinciding with the Acari National Park and the Ecological Station of Alto Maués, as well as the National Forests of Urupadi and Pau Rosa. Two other cadasters have 70 thousand hectares and 20 thousand hectares (ISA 2017:9).

The CAR has been broadly supported by international socio-environmental organizations. The Amazon Fund is an important financial supporter of the CAR. In the case of Amazonas state, the Fund allocated R\$ 29.867.722,00 for the implementation of the CAR on 55,588 rural properties with up to four fiscal modules in 36 municipalities through their inscription in the Rural Environmental Cadaster (CAR), and assisted Amazonas state to improve infrastructure for implementation of CAR. The Amazon Fund recognizes CAR as an inductor of production systems that are better adapted to the Amazon, allowing formal identification of those responsible for environmental infractions on the properties. The CAR, as an effective monitoring tool, has in recent years become the central instrument for international investment in environmental sustainability in the Amazon. According to the representation of The German Technical Cooperation Agency (GTZ), which also provides financing to CAR, the cadaster "is a good opportunity for two things: to know who is responsible for the land and to map land use on rural properties, which is essential to conduct sustainable forest management".

According to the representative of the Confederation of Agriculture and Husbandry of Brazil (CNA)', "CAR expresses the dimension of agriculture, the locomotive of economic development of Brazil, leading production and export of a dozen agricultural products. One thing is certain: the planning of Brazilian agriculture will make a qualitative leap". According to Márcio Bittar (MDB-AC), 10 "the data from CAR have been demonstrating that the farmer is the leading agent for environmental protection in the country".

\footnotetext{
9 José Zeferino Pedrozo - President of the Federation of Agriculture and Husbandry of Santa Catarina (Faesc) and of the National Rural Learning Service (SENAR/SC)

10 Author of the request to debate data from the Rural Environmental Cadaster (CAR) and environmental preservation, approved by the Senate Environment Commission.
} 
This configuration of financial capital stimulated the formalization of the market for public land available in the Amazon through the accelerated regulation promoted by state intervention to guarantee the prevalence of the private right to land in detriment to the public right to land for family farmers, the indigenous, artisan fishermen and traditional communities. Two processes are articulated in this logic of private appropriation and control of land: "the territorialization of the monopoly and monopolization of the territory" (Oliveira 2010).

\section{Final considerations}

Soon after he was elected in 2018, Jair Bolsonaro affirmed that his environmental minister "would come from the productive sector", making clear the reorientation of environmental policy in the country. This change was the object of a promise announced during the presidential campaign. In a discourse issued in regions in which Brazilian agribusiness prospers, he affirmed "not one centimeter more" would be conceded to the demarcation of indigenous lands, preaching the end of "Shiite ecological activism" or practices of environmental agencies that "harmed those who want to produce".

In the first semester of 2019, the campaign discourse became materialized in actions such as the rejection of millions of reals in resources from Norway and Germany for protection of the Amazon, and the decision to withhold financing for environmental monitoring actions by the federal agencies IBAMA and ICMBIO. In late August 2019, the eighth month of the new government, the Amazon registered 30,901 forest fires, an increase of 196\% over August 2018 (INPE,2019), exceeding the historic average from 1998-2018. Images of the Amazon in flames became national and international news.

The Federal Public Ministry (prosecutor's office), under public pressure, began investigations of denunciations referring to the so-called "Day-of-Fire", an event organized on 10 August 2019 by farmers, land grabbers and traders to start forest fires and clear a large area of land around federal highway BR-163, thus demonstrating support for President Bolsonaro's initiative to weaken environmental inspections by federal agencies. It should be emphasized that the federal public ministry in the interior of Pará warned the federal environmental agency Ibama about the planning for the "Day of Fire", which responded by alleging it could not act because of a lack of resources and support from the Pará state police and national security forces.

Only after a series of news reports and Brazilian and international mobilizations did the president call on the Federal Police to investigate charges of criminal action, given that the fires continued out of control in various parts of the Amazon. The large increase in fires in 2019, a year with a less intense dry period than in recent years, indicated that deforestation was a factor in spreading the flames, as proven in the comparison between the locations of the fires and the deforestation recorded from early 2019 until July. The ten Amazon municipalities with the most fires ${ }^{11}$ were also those that had the highest rates of deforestation in the period, therefore, the forest fires took place in recently deforested areas (IPAM 2019).

During the period of transition of government, the president-elect announced the fusion of the Ministries of Agriculture and the Environment, but reversed the idea days after protests from civil society, particularly socio-environmental organizations. The scene of Blairo Maggi, then Ministry of Agriculture, was emblematic; he was caught by the press leaving the house of the president after convincing him reverse the decision to combine the ministries. As we sought to demonstrate, the state reacted by attempting to balance the forces of agribusiness - which feared retaliations from large importers who did not want to buy products stained by destruction of the Amazon forest - and environmental groups that publicized the environmental aggressions to the forest, influencing global public opinion.

11 Among the ten municipalities in the Amazon with the most fires, three are in southern Amazonas: Apuí (1754 fires), Lábrea (1170 fires) and Novo Aripuanã (665 fires). 
Sectors linked to Brazilian agribusiness foresaw the possible financial cost from retaliations from international partners. The government discourse, insisting on minimizing the increase in deforestation, had caused apprehensions in relation to the future trade agreements and the possibility of a drop in exports. Agribusiness learned over recent decades about the delicate balance between market demand and protecting the Amazon Forest.

In this article I sought to show how changes in laws and regulations allowed a convergence of interests between international cooperation, the state and agribusiness around public policies for environmental regulations. The presumption that sustains these actions is that rural production and environmental conservation can coexist harmoniously through "recuperation and consolidation of sustainable landscapes, considering a positive and systematic alignment between the economy, the environment and people" (TNC 2015:31).

Received: June 26, 2019

Approved: October 2, 2019

Translated by: Jeff Hoff

\section{Bibliographic References}

ASAD, Talal. 1973. "Introduction". In: Anthropology \& the colonial encounter. Londres: Ithaca Press/ Humanities Press. pp. 9-19.

ALSTON, L.; MULLER, B. 2007. "Legal Reserve Requirements in Brazilian Forests: Path Dependent Evolution of De facto Legislation". EconomiA, Selecta, 8(4): 25-53.

ASSIS MOREIRA. 2012. “Corrida acelerada por terras agrícolas". Valor Econômico. https://valor.globo.com/ agronegocios/coluna/corrida-acelerada-por-terras-agricolas.ghtml Acesso em 26 Jun. 2019.

CHIAVARI, J.; LOPES, C. L. 2015. Novo Código Florestal - parte I: decifrando o novo Código Florestal. Rio de Janeiro: Input/ NAPC/PUC-Rio.

Comissão Mundial sobre Meio Ambiente e Desenvolvimento (CMMAD). 1998. Nosso futuro comum. Rio de Janeiro: Fundação Getúlio Vargas.

COMISSÃO PASTORAL DA TERRA. 2017. Conflitos no Campo Brasil. Goiania: CPT Nacional Brasil.

ESCOBAR, Arturo. 1995. Encountering development: the making and unmaking of the Third World. Princeton: Princeton University Press. . 2008. Territories of difference: place, movements, life, redes. Durham: Duke University Press.

FERGUSON, James. 1994. "The Anti-Politics Machine. Development and Bureaucratic Power in Lesotho". The Ecologist, 24(5): pp.176-181.

FERGUSON, J.; GUPTA, A. 2005. "Spatializing States: toward an ethnography of neoliberal governmentality". In: J.X. Inda (ed.), Anthropologies of modernity: Foucault, governmentality, and life politics. Malden: Blackwell Publishers. pp. 105-131. 
FUNDO AMAZÔNIA. 2017. Diretrizes e Critérios para Aplicação dos Recursos e Focos de Atuação para o Biênio 2017 e 2018. Mimeo.

GARNELO, L.; SAMPAIO, S. 2005. "Globalização e ambientalismo: etnicidades polifônicas na Amazônia”. História, Ciências, Saúde-Manguinhos, 12(3): 755-768.

GREENPEACE. 2006. Comendo a Amazônia. Amsterdã. Avaiable at: https:|/www.greenpeace.org/archivebrasil/Global/brasil/report/2007/7/comendo-a-amaz-nia.pdf. Accessed on: 06/26/2019.

HARVEY, David. 2004. O novo imperialismo. São Paulo: Edições Loyola. . 2016. 17 contradições e o fim do capitalismo. São Paulo: Boitempo. . 2001. "Políticas ambientais globais: o caso da biodiversidade". Caderno CRH, 35: 107-122.

INSTITUTO NACIONAL DE PESQUISAS ESPACIAIS (INPE). 2019. Programa Queimadas. Mimeo.

INSTITUTO DE PESQUISA AMBIENTAL DA AMAZÔNIA- IPAM. 2019. Amazônia em chamas. Nota técnica do Instituto de Pesquisa Ambiental da Amazônia. Mimeo.

MENEZES, Thereza C. 2011. "Dois destinos para o Purus: Desenvolvimentismo, sociambientalismo e emergência dos povos tradicionais no Sul do Amazonas". In: G. M. Santos (org.), Album Purus. Manaus: EDUA. pp.131-152.

. 2015. "A regularização fundiária e as novas formas de expropriação rural na Amazônia". Estudos Sociedade e Agricultura, 23(1): 110-130.

Ministério do Desenvolvimento Agrário. 2017. Avaiable at: http://www.mda.gov.br/sitemda/noticias/governofederal-lan\% $\mathrm{C}_{3} \% \mathrm{~A} 7 \mathrm{a}$-programa-nacional-de-regulariza $\% \mathrm{C}_{3} \% \mathrm{~A} 7 \% \mathrm{C}_{3} \% \mathrm{~A}_{3} \mathrm{o}$-fundi $\% \mathrm{C}_{3} \%$ Arria. Accesso em 18 Jun. 2019.

NITSCH, M. 1994. "Riscos do planejamento regional na Amazônia brasileira: observações relativas à lógica complexa do zoneamento”. In: Maria Angela d'Incao, Isolda Maciel Silveira (orgs.), Amazônia e a crise da modernização. Belém: Museu Paraense Emilio Goeldi. pp. 508.

INSTITUTO SOCIOAMBIENTAL (ISA). 2017. Nota Técnica sobre o Projeto de Lei de Redução e Revogação de Unidades de Conservação no Sul do Estado do Amazonas. Mimeo.

OLIVEIRA, A. 2010. "A questão da aquisição de terras por estrangeiros no Brasil - um retorno aos dossiês". Agrária, 12: 3-113.

PAULA, E. A. 2013. "Entre desastres e transgressões, a chegada dos imigrantes haitianos no "reino deste mundo amazônico". Novos Cadernos NAEA, 16(2):187-206.

RELATÓRIO DA COMISSÃO PARLAMENTAR DE INQUÉRITO destinada a investigar a ocupação de terras públicas na Região Amazônica.2001. Mimeo.

RIST, G. 2007. “Desenvolvimento como um modismo”. Development in Practice, 17(4-5):1-9. . 2008. The history of development: from western origins to global faith. $3^{\mathrm{a}} \mathrm{ed}$. London: Zed books

RELATÓRIO DE AUDITORIA DE CONFORMIDADE NO PROGRAMA TERRA LEGAL AMAZÔNIA- TCU. 2014. Avaiable at: http://pt.slideshare.net/fullscreen/SindPFA/relatrio-de-fiscalizao-do-programa-terra-legalpelo-tcu-2014/3. Acesso em 20 Jun. 2019.

SAID, E. 1990. Orientalismo: o Oriente como invenção do Ocidente. São Paulo: Companhia das Letras. SAVIAN, M.; MILHOMENS, A.; VALESE, M. C.; CABRAL, P.G.F. 2014. “Cadastro Ambiental Rural: Experiencias y Potencialidades para la gestión agroambiental”. In: R.H.R Sambuichi (org.), Políticas agroambientales y sostenibilidad: desafíos, oportunidades y lecciones aprendidas. Brasília: IPEA. pp. 105-124. SOUZA LIMA, Antonio Carlos de (org.).2012. Gestar e gerir: estudos para uma antropologia da administração pública no Brasil. Rio de Janeiro: Relume-Dumará. 
TEIXEIRA, Gerson. 2011. “Agravamento do quadro de Concentração da Terra no Brasil”. Boletim DATALUTA. NERA - Núcleo de Estudos, Pesquisas e Projetos de Reforma Agrária - Avaiable at: www.fct.unesp.br| nera1. Accesso em 25 Jun. 2019.

THE NATURE CONSERVANCY- TNC. 2015. Cadastro Ambiental Ruaral - CAR: Nasce a Identidade do Imóvel Rural. Curitiba.

TORRES, M; BRANFORD, S. 2017. "Após mais de uma década, pacto voluntário entre empresas e ONGs deixa dúvidas sobre eficácia em proteger a Amazônia". Avaiable at: https:|/theintercept.com/2017/03/16/ moratoria-da-soja-solucao-contra-o-desmatamento-ou-marketing-corporativo/. Accesso em $25 \mathrm{Jun}$. 2019.

VALENTE, Renata C. A. 2010. GTZ no Brasil: Uma etnografia da cooperação alemã para o desenvolvimento. Rio de Janeiro: E-papers/UFRJ/ Laced.

Thereza Cristina Cardoso Menezes

Federal Rural University of Rio de Janeiro; Graduate Program in the Social Sciences in Development, Agriculture and Society (CPDA-UFRRJ)

https://orcid.org/0000-0003-2452-0433

Email: therezaccm@uol.com.br 